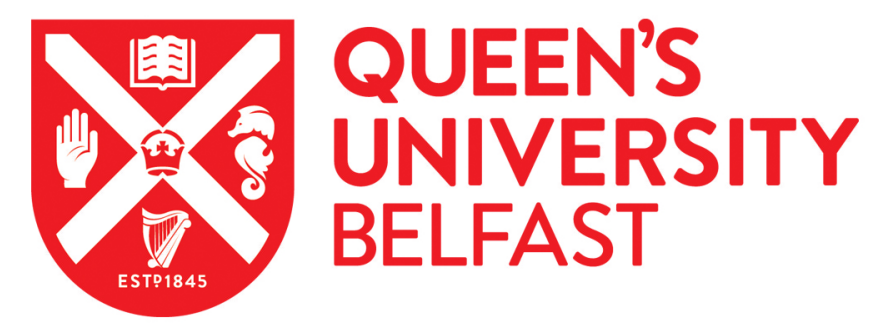

\title{
Performance of biochar as a catalyst for tar steam reforming: Effect of the porous structure
}

Buentello-Montoya, D., Zhang, X., Li, J., Ranade, V., Marques, S., \& Geron, M. (2020). Performance of biochar as a catalyst for tar steam reforming: Effect of the porous structure. Applied Energy, 259, [114176].

https://doi.org/10.1016/j.apenergy.2019.114176

\section{Published in:}

Applied Energy

\section{Document Version:}

Peer reviewed version

Queen's University Belfast - Research Portal:

Link to publication record in Queen's University Belfast Research Portal

\section{Publisher rights}

(C) 2020 Elsevier Ltd.

This manuscript version is made available under the CC-BY-NC-ND 4.0 license http://creativecommons.org/licenses/by-nc-nd/4.0/,which permits distribution and reproduction for non-commercial purposes, provided the author and source are cited.

\section{General rights}

Copyright for the publications made accessible via the Queen's University Belfast Research Portal is retained by the author(s) and / or other copyright owners and it is a condition of accessing these publications that users recognise and abide by the legal requirements associated with these rights.

Take down policy

The Research Portal is Queen's institutional repository that provides access to Queen's research output. Every effort has been made to ensure that content in the Research Portal does not infringe any person's rights, or applicable UK laws. If you discover content in the Research Portal that you believe breaches copyright or violates any law, please contact openaccess@qub.ac.uk. 


\title{
Performance of biochar as a catalyst for tar steam reforming: effect of the porous
}

\section{structure}

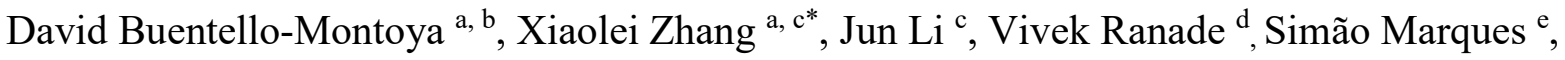
Marco Geron ${ }^{\text {a }}$

${ }^{\text {a }}$ School of Mechanical and Aerospace Engineering, Queen's University Belfast, Belfast BT9 5AH, United

Kingdom.

${ }^{\mathrm{b}}$ Escuela de Ingeniería y Ciencias, Tecnologico de Monterrey, Zapopan 45138, México.

${ }^{c}$ Department of Chemical and Process Engineering, University of Strathclyde, Glasgow G1 1XJ, United

Kingdom

${ }^{\mathrm{d}}$ School of Chemistry and Chemical Engineering, Queen's University Belfast, Belfast BT9 5AG, United

Kingdom.

${ }^{\mathrm{e}}$ Department of Mechanical Sciences and Engineering, University of Surrey, Guildford GU2 7XH, United

Kingdom.

*Corresponding author: Tel.: +44(0) 141548 4131, E-mail address: xiaolei.zhang@strath.ac.uk, Address: 75

Monrose St G1 1XJ, Glasgow, United Kingdom.

\begin{abstract}
The application of gasification to thermally treat biomass as carbon neutral resources has been constrained by the technical challenges associated with tar formations, which cause operational problems in downstream equipment for syngas processing. Catalysts, such as transition metals, calcined rocks and char, can be used to catalyse tar reforming. Biochars, which are naturally produced during biomass gasification, are particularly attractive as an alternative catalyst due to their catalytic functions, low cost and long endurance. Despite these promising characteristics, adequate knowledge on the relationship between the porous structure of biochar and its deactivation by coking during the steam reforming of tars is not available. In this work, the influence of the porous structure of biochar on its performance across time for reforming tar was investigated in a fixed-bed reactor, over a temperature range from 650 to $850^{\circ} \mathrm{C}$. Regular biochar and physically activated biochar from the same precursor biomass were employed as bed material. The tar samples were the composed mixture of benzene, toluene and naphthalene. Both fresh and spent catalysts were analysed with Brunauer-Emmet-Teller, tplot, Fourier Transform Infrared and Scanning Electron Microscopy/Energy Dispersive Spectroscopy. Results showed that, while at moderate temperatures of 650 and $750{ }^{\circ} \mathrm{C}$, the activated biochar offered a higher tar conversion but more severe deactivation than that of the regular biochar. At the high temperature of $850{ }^{\circ} \mathrm{C}$, the difference in the catalytic performance between the two chars was negligible, and over $90 \%$ of the initial tar species were removed throughout the 3-hour long experiments. At $850{ }^{\circ} \mathrm{C}$, the coke deposited in the meso- and macro-pores of both chars was gasified, leading to a stable catalytic performance of both chars. The results indicated that meso- and macro-porous biochars are resilient and active enough to become a viable option for tar steam reforming.
\end{abstract}

Keywords: Syngas, tar reforming, catalyst, catalyst deactivation, activated char, char

\section{Number of words: 5,757}

\author{
Abbreviations \\ $A C \quad$ Activated biochar \\ $B E T \quad$ Brunauer-Emmet-Teller \\ $C A C \quad$ Coked activated biochar \\ EDS Energy Dispersive Spectroscopy \\ FTIR Fourier Transform Infrared \\ HPLC High-performance liquid chromatography
}




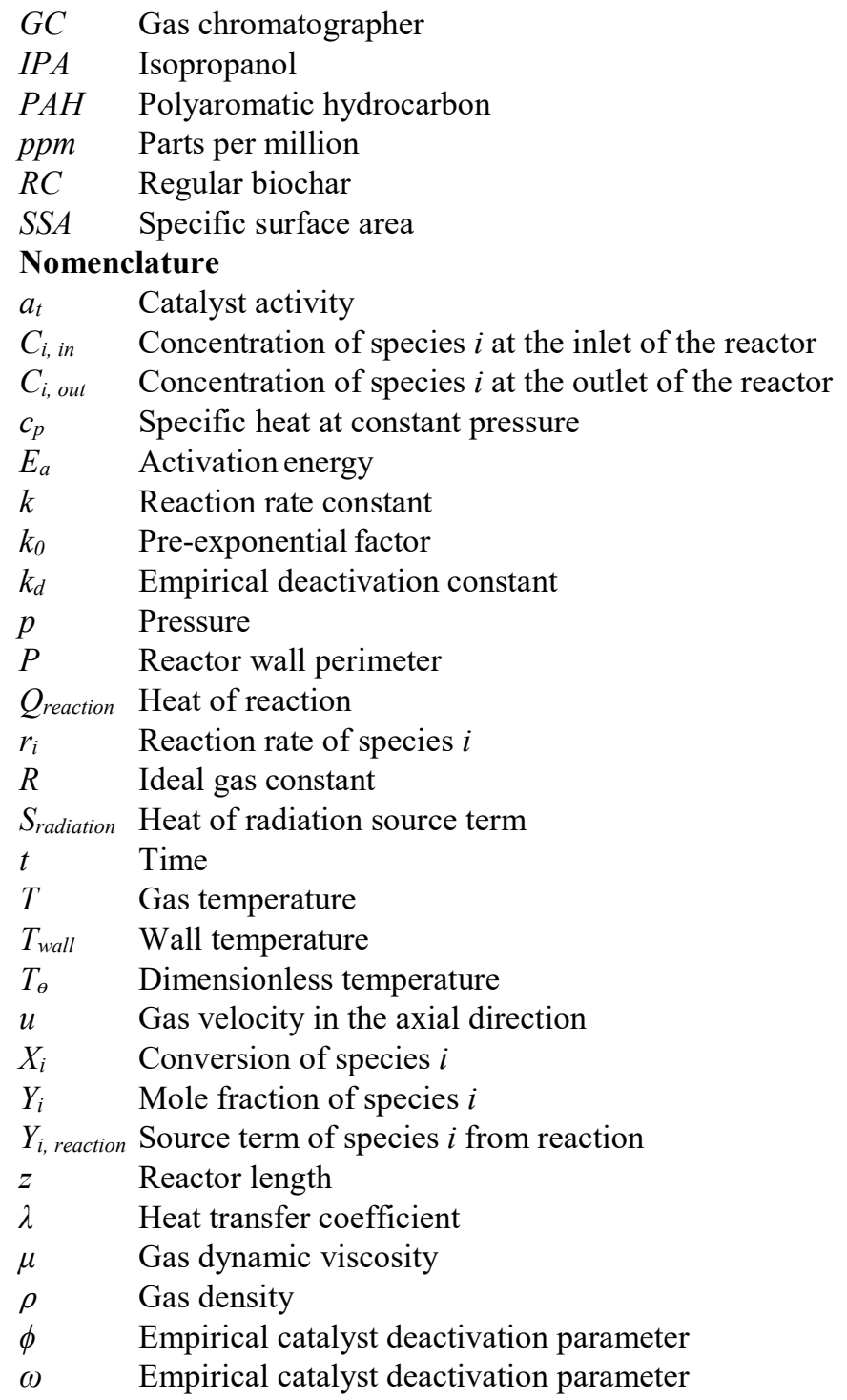

\section{Introduction}

The environmental concern together with the exhaustion of fossil fuels has attracted the attention of humankind towards renewable energies such as solar, wind and biomass energy. Within all the types of renewable energies, biomass is carbon-neutral and plays a significant role to meet the demands on energy and fuels. Biomass gasification is a promising technology. The produced gases are versatile and have various applications, e.g. power generation using gas turbines or production of liquid fuels via the Fischer-Tropsch process [1,2]. However, as promising as the technology sounds, a recurring limitation for biomass gasification is found in the generation of some undesirable compounds such as tars, which are notoriously hard to remove [1].

Tars are a mixture of heavy aromatic hydrocarbons with diverse chemical structures and characteristics. Examples of tars include heterocyclic compounds such as pyridine, aromatic compounds such as toluene and polyaromatic hydrocarbons (PAH) such as naphthalene. Tars from gasification lead to severe problems in the downstream processing equipment, e.g., clogging and blockage. Because of this, great effort has been placed to develop efficient tar removal methodologies, classified as physical, thermal or catalytic treatments. Physical tar removal is relatively simple, and it works in a way of transferring tars into a different phase rather than 
destroying them, thus requires additional treatment. This constrains the application of physical tar removal technologies both environmentally and economically [3]. Thermal cracking involves the degradation of tars into lighter hydrocarbons (i.e. $\mathrm{CO}$ and $\mathrm{H}_{2}$ ), therefore tars are effectively destroyed; however, the required operation temperatures are exceedingly high, e.g. $1300^{\circ} \mathrm{C}$ for degradation of naphthalene, $1100{ }^{\circ} \mathrm{C}$ for benzene and $950^{\circ} \mathrm{C}$ for toluene [4]. By comparison, catalytic treatments can deliver over $95 \%$ tar removal at relatively lower temperatures (ca. $800^{\circ} \mathrm{C}$ ). Moreover, during catalytic treatments, the tars react with a reforming agent such as steam or $\mathrm{CO}_{2}$ to yield $\mathrm{H}_{2}$ and $\mathrm{CO}$ as products, increasing the heating value of the product gas. Although promising, catalytic reforming is limited by catalysts deactivation due to coke deposition, catalyst poisoning or structural collapse $[3,5-7]$.

Char has been proven to be a capable catalyst of reforming tars. Due to the fact that char is naturally produced during the gasification process, its utilization as catalyst presents an added value by potentially reducing waste handling costs [8]. The tar removal efficiency using different popular catalysts were compared by El-Rub et al. [9] and it was found that char can provide conversions as high as those provided by Ni-based catalysts $(>90 \%)$.

The char-catalytic tar reforming performance is affected by various factors, including: (1) the physicochemical characteristics of char, e.g. particle size [10], surface area [11-17], (2) the presence of ashes (i.e. inorganic species) on its surface [11,12]; and (3) operation parameters, e.g. the tar concentration, steam concentration[10,14], or temperature $[9,10,14]$. El-Rub et al. [10] tested the effects of these influential factors on the reduction of naphthalene, and concluded that temperature is the most significant factor that affects tar decomposition, and the effect of the tar concentration is less significant in the conversion. Hervy et al. [13] determined that the char deactivation mechanism depends on its physicochemical characteristics. It was found that when the char contains a high amount of fixed carbon, deactivation will occur due to pore coking. FuentesCano et al. [14] studied on employing chars from different sources for reforming toluene and naphthalene, and found that at a certain temperature and in the presence of steam, the reforming activity will remain constant. Moreover, the authors determined that while the nature of the feedstock used to produce the chars had an effect in the char catalytic capabilities, the qualitative behavior of the activity across time did not depend on the type of char.

It has been proven that both surface area and inorganic species are important factors for catalytic reforming of tar, and a synergy exists, i.e. highly porous chars with inorganic species can provide higher tar conversions $[16,17]$. Hosokai et al. [15] studied the decomposition of benzene and naphthalene using char and varying the composition of the reforming gases, and concluded that the micropore surface area is a key aspect for naphthalene reforming. Moreover, it was reported that under an inert atmosphere, chars with a large surface area take longer to be deactivated. On the other hand, if the char has a high content of ashes, inorganic species contained in ashes will migrate to the char surface and block active sites. Korus et al. [18] assessed the toluene degradation in the presence of activated coal char and determined that the char serves as an adsorbent, and radicals in the char surface influence the conversion of the tar. Acharya et al. [19] compared regular and commercial activated char for the adsorption of toluene and $\mathrm{CO}$ production, it was found that the activated char performed better and showed capabilities for adsorption at low temperatures, after a certain operation time, the char became saturated with toluene and the adsorption stopped. 
Previous studies have shown that char surface area is important factor for tar reforming, however, the influences of the char porous structure on tar reforming and coke gasification are not well understood [13-15]. Work has been done to analyze the effect of the porous structure on the char activity during pyrolysis [13,20], and comprehensive assessment on the influence of the char porosity on catalytic steam reforming of tars across time. For this reason, this study is dedicated to analyzing the effect of the structure of biochar during the catalytic steam reforming of a synthetic tar mixture at different temperatures for three hours. Regular biochar and physically activated biochar from the same precursor biomass were utilized as catalysts. The two types of chars have different porous structures but the same inorganic species, ensuring that any differences in catalytic effects are owed to physical features and not chemical characteristics altered during chemical activation. Physical char activation with $\mathrm{CO}_{2}$ was chosen because it does not have an effect in the present inorganic species (i.e. it does not participate as an oxidizer for the inorganic species, as the Boudouard reaction is more thermodynamically favoured) and $\mathrm{CO}_{2}$ is known to promote the formation of micropores [21,22]. Model compounds representative of certain tar classes were selected and employed in the experiments: benzene was used as an intermediary tar always present in tar mixtures, toluene was used as a stable alkyl aromatic and naphthalene was used as a stable polyaromatic hydrocarbon [22]. In addition to experimental results, chemical kinetics (including deactivation kinetics) were obtained and are presented with the finality of comparing the findings from this work with existing literature. Overall, since biomass gasification is largely constrained by either the presence of tars in the produced gas or the deactivation of the catalysts used for tar reforming, the results obtained from this research contribute to the viability of biomass gasification as a source of renewable energy.

\section{Methodology}

\subsection{Experimental setup and procedure}

The experimental setup is illustrated in Figure 1. The reactor employed in this work consisted of an electrically-heated fixed-bed drop tube reactor. The dimensions of the reactor were $47 \mathrm{~cm}$ long and $2.66 \mathrm{~cm}$ in diameter. The bed zone, placed in the middle of the reactor, was approximately $7 \mathrm{~cm}$ tall. The bed height and the gas flow rate were adjusted so the gas residence time through the bed, calculated as a function of the void volume in the bed, was around 0.5 seconds. A fixed quartz sinter inside the reactor was used to support the bed, and during packing, the reactor was shaken and the particles were pressed against the bottom of the reactor to reduce the void space between particles. The reactor and pipes were insulated to prevent heat losses and avoid tar condensation during the experiments. 


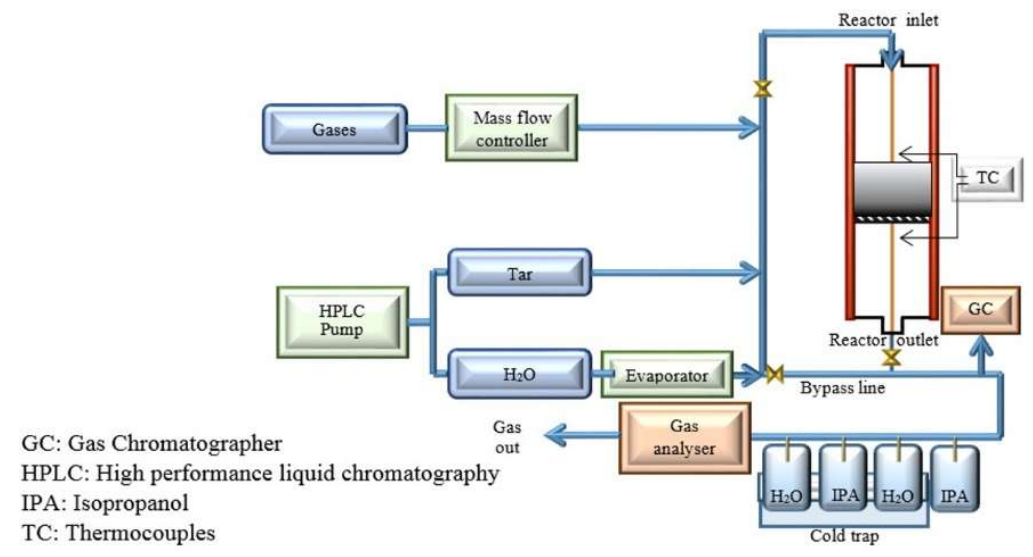

Figure 1. Illustration of the reactor setup for the experiments.

Experiments were conducted at atmospheric pressure and temperatures of 650,750 and $850{ }^{\circ} \mathrm{C}$ for 3 hours to investigate the evolution of the catalyst activity over time. The temperature in the reactor was constantly measured via K-type thermocouples located just above the catalyst bed and at the outlet of the reactor. The measured temperatures showed a variation of less than $1{ }^{\circ} \mathrm{C}$ during the experiments. Before each experiment and after packing, the reactor was heated to $650{ }^{\circ} \mathrm{C}$; afterwards, a pure $\mathrm{N}_{2}$ stream was injected for at least 1 hour to dry the bed and purge the reactor of any present gas. Subsequently, the reactor was heated to the desired operation temperature. When the measured temperature stabilized, a gas mixture with volume composition of $25.1 \% \mathrm{CO}, 23.7 \% \mathrm{CO}_{2}, 7 \% \mathrm{CH}_{4}, 16.8 \% \mathrm{H}_{2}$ and $27.4 \% \mathrm{~N}_{2}$ was injected via mass flow controllers. The permanent gases were mixed with a stream consisting of steam and a solution of tar model compounds. The tars were injected using a High Performance Liquid Chromatography (HPLC) pump, the tar concentration in the mixture was $20 \mathrm{~g} / \mathrm{Nm}^{3}$, and the proportions for benzene, toluene and naphthalene in the mixture were 61.34, 23.13 and 15.53 wt. \%, respectively; the distribution of benzene, toluene and naphthalene in the overall tar composition was based on average amount of tars of their respective class reported in literature [23]. The wet gas composition of the resulting mixture was approximately, in volume, $18 \% \mathrm{CO}, 17 \% \mathrm{CO}_{2}, 5 \% \mathrm{CH}_{4}, 12 \%$ $\mathrm{H}_{2}, 20 \% \mathrm{~N}_{2}$ and $28 \% \mathrm{H}_{2} \mathrm{O}$ (steam).

\subsection{Catalyst preparation and characterization}

The catalyst consisted of residual gasification biochar, which were obtained from the pyrolysis of hardwood. The biochar particles were used either straight from pyrolysis (called regular biochar, abbreviated as RC) or after being physically activated (called activated biochar, abbreviated as AC). Additional experiments were conducted using a non-catalytic inert bed (silicon carbide, $\mathrm{SiC}$ ) to compare the extent of degradation of the tars by thermal cracking or catalytic cracking. For the activation of the char, char particles were placed inside the reactor and heated to $750{ }^{\circ} \mathrm{C}$. When the measured temperature stabilized, a stream composed by a mixture of $35 / 65$ vol. \% of $\mathrm{CO}_{2} / \mathrm{N}_{2}$ was injected to the reactor for 2 hours to activate the char. $\mathrm{CO}_{2}$ was chosen as an activating agent because it is known to favor the formation of micropores and -O groups in the char surface, leading to high reactivity [2426]. The amount of $\mathrm{CO}_{2}$ injected was $280 \mathrm{~mL} / \mathrm{min}$ and the amount of nitrogen was adjusted to the desired flowrate. The flow rates were adjusted to prevent pressure drops in the reactor and having burnout rates of around $25 \%$ [27]. Proper activation temperature was selected as $750{ }^{\circ} \mathrm{C}$, based on facts that higher temperatures lead to pore sintering, while lower temperatures lead to slower micropore development [28-30]. Additionally, $750{ }^{\circ} \mathrm{C}$ is a 
temperature low enough to ensure that the inorganic species in the char matrix will not migrate to the surface and block the char pores [11]. On the other hand, the activation time was chosen as 2 hours to ensure sufficient micropore area, because the activation reaction rate with $\mathrm{CO}_{2}$ is known as lower than that with steam [24,31,32].

Sieving and structural characterization of the particles was conducted before and after the experiments. The particles were crushed and sieved to sizes between 200 and $400 \mu \mathrm{m}$ to reduce the effects of diffusion. The surface area was measured via nitrogen adsorption-desorption at 77K (Micromeritics TriStar II 3020). Brunauer-EmmetTeller (BET) theory was used to calculate the surface areas while for the micropore areas and volume, t-plot method was employed. Fourier Transform Infrared (FTIR) (Perkin Elmer Spectrum 2) analysis was conducted on the char and the results were compared with available literature to identify surface functional groups [33,34]. Additionally, Scanning Electron Microscopy (SEM) (HITACHI FlexSEM 1000) was used to identify the surface features of the chars, and the Energy Dispersive Spectroscopy (EDS) (HITACHI FlexSEM 1000) analysis was conducted to ascertain whether or not there was a difference in the inorganic contents between the regular and activated chars. To analyse the char particles with SEM/EDS, the particles were mounted over resin (as binding material) and were coated with a gold layer to ensure electric conduction [35].

\subsection{Gas sampling and analysis}

The tar species were analysed by a Gas Chromatographer (GC) (Agilent 7890A) connected to the outlet of the reactor. Chromatogram data was obtained every 30 minutes to determine the changes in conversion due to catalyst deactivation. Subsequently, the tar species were recovered using an ice trap with $\mathrm{H}_{2} \mathrm{O}$ and isopropanol (IPA) while the permanent gases $\left(\mathrm{CO}, \mathrm{CO}_{2}, \mathrm{CH}_{4}, \mathrm{H}_{2}, \mathrm{~N}_{2}\right)$ were directed to an online gas analyzer (Sick Maihak S710) for characterization before being recovered. The information on the permanent gases was collected by the gas analyzer every minute.

\subsection{Determination of kinetic parameters}

A pseudo-homogeneous model was used for the determination of kinetic parameters of tar reforming. A relationship (Eq. 1) following Arrhenius equation was utilized for all the tar species, with the reaction rate and rate constant defined as:

$$
\begin{aligned}
& -r_{i}=k C_{i} \\
& k=a_{t} k_{0} e^{-E a / R T}
\end{aligned}
$$

where $r_{i}$ and $C_{i}$ are the reaction rate and concentration for tar species $i$, respectively; $k$ is the apparent reaction rate constant; $k_{0}$ is the pre-exponential factor; $E_{a}$ is the activation energy; $R$ is the ideal gas constant; $T$ is the gas temperature and $a_{t}$ is the catalyst activity at time $t$. The reaction rate was assumed to be first-order with respect to the tars $[10,36]$. Tar conversion is defined in Eq. 3, and the apparent rate constant as a function of conversion was calculated with Eq. 4:

$$
X_{i}=\frac{C_{i, \text { in }}-C_{i, \text { out }}}{C_{i, \text { in }}}
$$




$$
\frac{d X_{i}}{d t}=k\left(1-X_{i}\right)
$$

where $X_{i}$ is the conversion of the species $i ; C_{i, \text { in }}$ and $C_{i, \text { out }}$ are the concentrations of species $i$ at the inlet and the outlet of the reactor, respectively; $t$ is the gas residence time travel through the catalyst bed materials, defined by:

$$
t=C_{i, \text { in }} \int_{0}^{X_{i, \text { out }}} \frac{d X_{i}}{-r_{i}}
$$

where $X_{i, \text { out }}$ is the conversion of the species $i$ at the outlet of the reactor.

The deactivation of the catalyst was modelled following the methodology as described in $[14,37,38]$, the catalyst activity is empirically defined as a function of time and temperature :

$$
a_{t}=\frac{1}{k_{d} t^{\phi+\omega T_{\theta}}+1}
$$

where $k_{d}, \phi$ and $\omega$ are parameters adjusted to account for the amount of coke in the catalyst surface, $\phi$ and $\omega$ are empirical constants unique for each species and operating temperature, empirically adjusted to fit the measured conversions across time [37,38]. $T_{\theta}$ is a dimensionless temperature to account for the variation of the coke formation with increasing of temperature, and defined as:

$$
T_{\theta}=\frac{T}{1173 K}
$$

\subsection{Computational model}

Simulations of the char catalytic tar reforming employing the collected kinetics were conducted using the computational chemistry suite Cantera [39]. The validation of the kinetics was conducted by reproducing the experiments. The reactor was modeled as a one-dimensional plug flow reactor, with governing equations for continuity, conservation of momentum, energy and species, respectively, defined as:

$$
\begin{gathered}
\frac{d \rho}{d t}+\frac{d \rho u}{d z}=0 \\
\rho u \frac{d u}{d z}=-\frac{d p}{d z}-\mu \frac{d^{2} u}{d z^{2}} \\
\rho u c_{p} \frac{d T}{d z}=P \lambda\left(T_{\text {wall }}-T\right)+Q_{\text {reaction }}+S_{\text {radiation }} \\
\rho u \frac{d\left(Y_{i}\right)}{d z}=Y_{i, \text { reaction }}
\end{gathered}
$$

where $\rho$ is the gas density, $z$ is axial direction, $p$ is pressure, $\mu$ is gas dynamic viscosity, $c_{p}$ is the specific heat at constant pressure, $\lambda$ is the heat transfer coefficient with surrounding walls, $P$ and $T_{\text {wall }}$ are the perimeter and temperature of the wall surrounding the gas, $Q_{\text {reaction }}$ is the heat of reaction, $S_{\text {radiation }}$ is the source term from radiative heat transfer, $Y_{i}$ is the mole fraction of species $i$ and $Y_{i, \text { reaction }}$ is the reaction source term for species $i$. 


\section{Results}

\subsection{Conversion of tar compounds}

When comparing the experimental results with the inert bed and catalytic bed, it was found that there was no tar been converted in the inert bed. This was expected since it is known that temperatures of at least $1273 \mathrm{~K}$ are required to degrade the studied tars [4]. The initial tar conversions, measured right after the experiments began, on the char catalytic bed as a function of temperature can be found in Figure 2; more details related to the concentrations at the reactor outlet can be found in the supplementary information, Figure S1. For every operation temperature the highest conversions were obtained using the $\mathrm{AC}$ bed. The tar conversions using RC were $7 \%$ at $650{ }^{\circ} \mathrm{C}, 28 \%$ at $750^{\circ} \mathrm{C}$ and $90 \%$ at $850{ }^{\circ} \mathrm{C}$, while the tar conversions obtained using AC were $11 \%$ at $650{ }^{\circ} \mathrm{C}, 48 \%$ at $750^{\circ}$ and $91 \%$ at $850{ }^{\circ} \mathrm{C}$. The differences in the catalyst activity were especially noticeable at $750^{\circ} \mathrm{C}$, where the conversion for benzene, toluene and naphthalene using $\mathrm{AC}$ were 17,19 and $27 \%$ higher than that of using RC. By comparison, at $850^{\circ} \mathrm{C}$ the conversions obtained with both char catalysts were virtually the same: conversions for toluene and naphthalene were more than $95 \%$, while for benzene they were about $85 \%$.

The tar conversions were calculated across time from the results obtained from the GC analysis each 30 minutes as shown in Figure 3. Decreases in conversion over the operating time are observed for both catalysts, the decrease was more significant when using $\mathrm{AC}$ than that of $\mathrm{RC}$. For example, at $750^{\circ} \mathrm{C}$ the total tar conversion using $\mathrm{AC}$ decreased from 48 to $23 \%$ after 3 hours; while at the same temperature and after the same operation time, the total tar conversion using RC decreased from 24 to $22 \%$. Therefore, although the initial conversions were higher with activated char, the catalyst lost activity until reaching a plateau where the obtained conversions were about the same as those provided by the regular char. The decreases in conversion of naphthalene and toluene across time at $850^{\circ} \mathrm{C}$ for both chars were less than $10 \%$ while the reduction in benzene conversion was about $25 \%$; for every case the decrease was slightly more significant in the activated char.

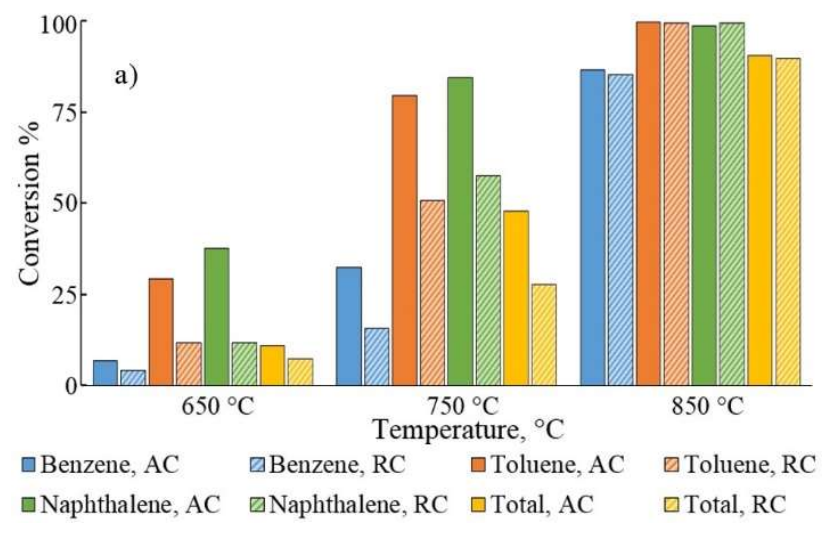

Figure 2. Initial catalytic tar conversions as a function of temperature. 

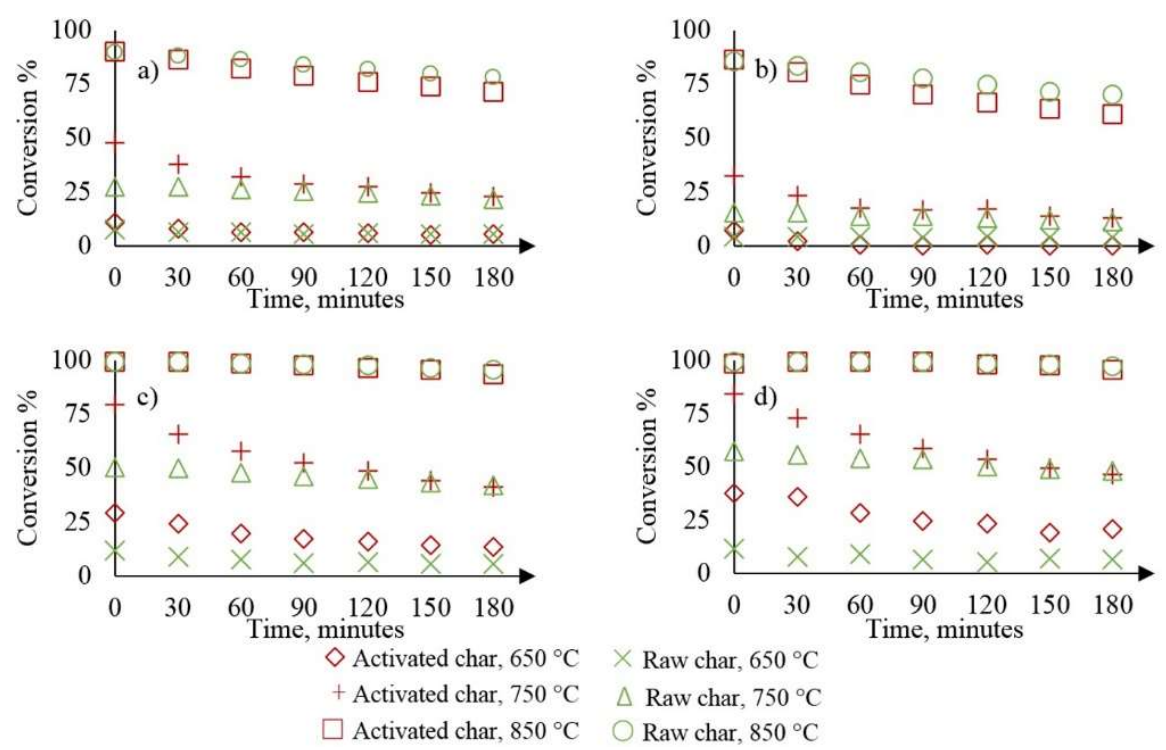

Figure 3. Catalytic tar conversion across time at different temperatures. a) Total tar conversion, b) benzene conversion, c) toluene conversion and d) naphthalene conversion.

The decay in the activity indicates that the deactivation (i.e. coke deposition rate) of the char is more significant at 650 and $750{ }^{\circ} \mathrm{C}$, although the injected steam could active the char in-situ during reforming. Contrarily, at 850 ${ }^{\circ} \mathrm{C}$ the activity is preserved, thus it can be inferred that the gasification rate of char/coke at least equals the rate of coke deposition.

\subsection{Products from tar conversion}

Figure 4 describes the tar reforming products at the outlet of the reactor using $\mathrm{AC}$ and $\mathrm{RC}$ beds. The $\mathrm{H}_{2}$ contents increased with the increasing of temperature. At $650{ }^{\circ} \mathrm{C}, \mathrm{H}_{2}$ originated from the tar reforming and the thermodynamically favored water-gas shift reaction [40]. The greatest $\mathrm{H}_{2}$ increase $(54 \%)$ was seen at $850{ }^{\circ} \mathrm{C}$, owing to the reforming of the tars and methane; this was also reflected in the increases in $\mathrm{CO}$ content. At $850{ }^{\circ} \mathrm{C}$ there was a noticeable decrease in $\mathrm{CO}_{2}$ due to the reverse Boudouard reaction.

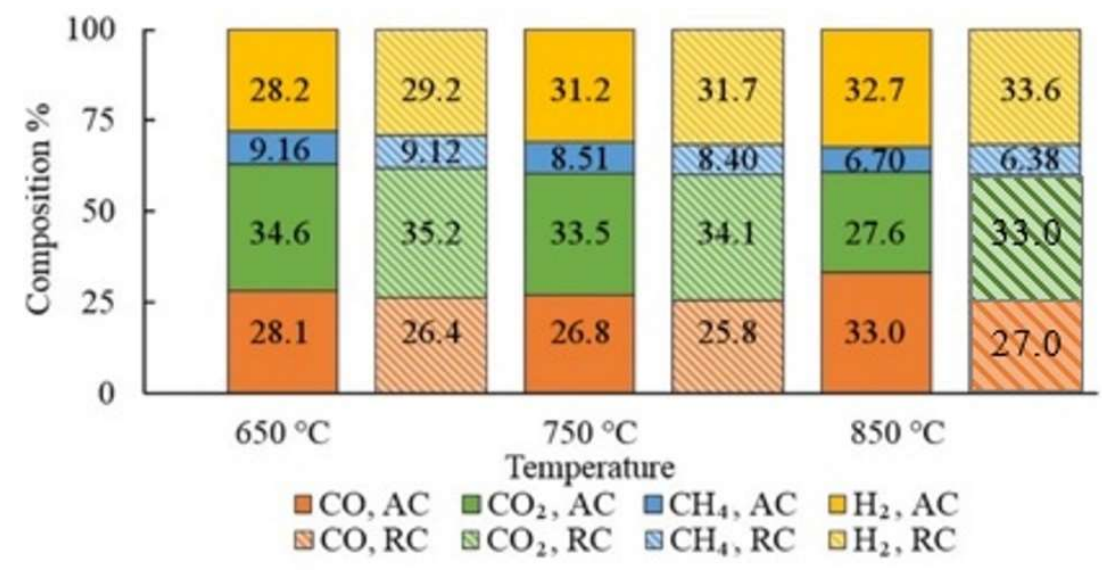

Figure 4. Distribution of species at the outlet of the reactor using a fresh catalyst, in volume \%.

Figure 5 shows the percent changes in the product fractions at inlet and outlet of the reactor from the experiments across time. For the 650 and $750^{\circ} \mathrm{C}$ experiments, with both catalysts the measured concentrations 
of $\mathrm{H}_{2}, \mathrm{CO}_{2}$ and $\mathrm{CH}_{4}$ were almost constant during the 180 minutes of operation. At $850^{\circ} \mathrm{C}$ there were some changes in the products at the outlet. The produced $\mathrm{H}_{2}$ decreased, in volume percentage, from $55 \%$ to $45 \%$ using RC, and from $47 \%$ to $40 \%$ when using the AC bed (Figure 5a). With regards to CO (Figure 5b), at 650 and $750{ }^{\circ} \mathrm{C}$ changes were less than $3 \%$, while at $850{ }^{\circ} \mathrm{C}$ a decrease of about $7 \%$ was detected using both catalysts. $\mathrm{CO}_{2}$ and $\mathrm{CH}_{4}$ (Figure 5c and d) behaved similarly, showing negligible changes in concentration at 650 and 750 ${ }^{\circ} \mathrm{C}$ while showing increases of about $7 \%$ at $850{ }^{\circ} \mathrm{C}$.
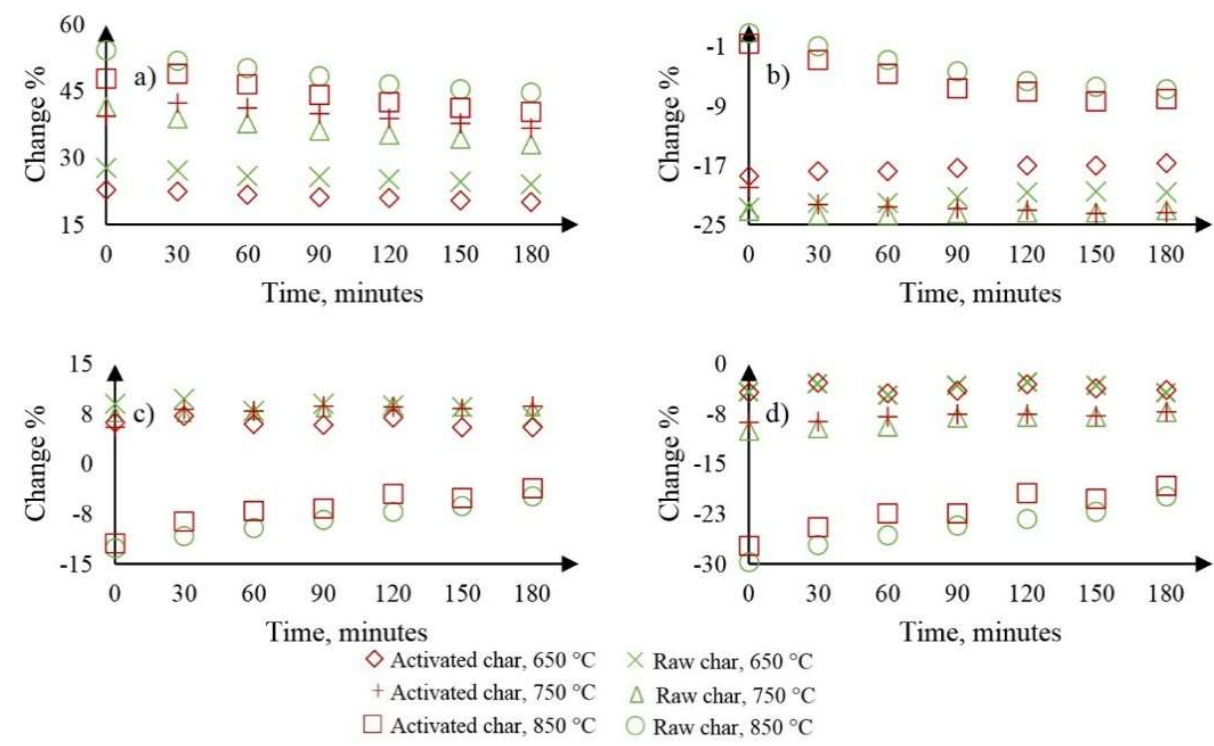

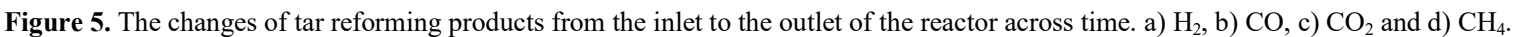

\subsection{Kinetic model}

The reactions found in Table 1 were proposed as a reduced mechanism derived from the observed tar conversions and product compositions. The influence of internal and external mass transfer to the catalyst were determined by calculating the effectiveness factor and Damköhler numbers [41]. At all the experiment temperatures, the calculated values for effectiveness factor were practically one, while the values for Damköhler number at the lowest operation temperature $\left(650^{\circ} \mathrm{C}\right)$ were $0.001,0.007$ and 0.01 for benzene, toluene and naphthalene, respectively. This indicates that internal and external diffusion phenomena did not play an important role in the reactions and therefore can be neglected in the kinetic model $[41,42]$. On the other hand, the correlation factors calculated when estimating the kinetic parameters using Arrhenius plots were above 0.95 for every case. In every case, the activation energies required for tar decomposition using regular char than those using activated char. In terms of the parameters calculated to simulate the catalyst deactivation, generally, the values associated to the regular char indicated a stronger activity-temperature relationship.

Table 1. Reduced mechanism for catalytic tar reforming

\begin{tabular}{|c|c|c|c|c|c|c|c|c|c|c|c|c|}
\hline \multirow[t]{2}{*}{ Reaction } & \multicolumn{2}{|c|}{$k_{0}$} & \multicolumn{2}{|c|}{$E_{a}, \mathrm{~kJ} / \mathrm{mol}$} & \multicolumn{2}{|c|}{$k_{d}$} & \multicolumn{2}{|c|}{$\phi$} & \multicolumn{2}{|c|}{$\omega$} & \multicolumn{2}{|c|}{$r^{2}$} \\
\hline & $\mathrm{AC}$ & $\mathrm{RC}$ & $\mathrm{AC}$ & $\mathrm{RC}$ & $\mathrm{AC}$ & $\mathrm{RC}$ & $\mathrm{AC}$ & $\mathrm{RC}$ & $\mathrm{AC}$ & $\mathrm{RC}$ & $\mathrm{AC}$ & $\mathrm{RC}$ \\
\hline $\mathrm{C}_{6} \mathrm{H}_{6}+6 \mathrm{H}_{2} \mathrm{O} \rightarrow 6 \mathrm{CO}+9 \mathrm{H}_{2}$ & $1.98 \times 10^{7}$ & $9.79 \times 10^{7}$ & 144 & 162 & $5 \times 10^{-3}$ & $3 \times 10^{-3}$ & 2.6 & 2.5 & -1.4 & -1.4 & 0.99 & 0.95 \\
\hline $\mathrm{C}_{7} \mathrm{H}_{8}+7 \mathrm{H}_{2} \mathrm{O} \rightarrow 7 \mathrm{CO}+11 \mathrm{H}_{2}$ & $3.27 \times 10^{6}$ & $2.51 \times 10^{8}$ & 118 & 160 & $2 \times 10^{-3}$ & $2 \times 10^{-3}$ & 2.6 & 2.6 & -1.3 & -1.6 & 0.99 & 0.99 \\
\hline $\mathrm{C}_{10} \mathrm{H}_{8}+10 \mathrm{H}_{2} \mathrm{O} \rightarrow 10 \mathrm{CO}+14 \mathrm{H}_{2}$ & $2.68 \times 10^{5}$ & $2.21 \times 10^{8}$ & 95.7 & 159 & $5 \times 10^{-3}$ & $3 \times 10^{-3}$ & 2.8 & 2.6 & -1.7 & -1.6 & 0.99 & 0.99 \\
\hline
\end{tabular}

Results from simulations and experiments through time are found in Figure 6. There were deviations from the experiments in the predictions of the benzene conversion across time; it can be found that, for the operating time 
less than 4 hours, the most significant differences occurred at $650{ }^{\circ} \mathrm{C}$ using activated char; these maximum differences were less than $8 \%$, thus the model fits accurately at higher operation temperatures, where desirable conversion values were obtained. Additional simulations were conducted with the operation time extrapolated up to 10 hours. It was shown that the toluene and naphthalene conversions provided by the RC were over $90 \%$. After the same period of time, the benzene conversion suffered a decrease of about $40 \%$. For the AC, the conversion decreased steadily to a minimum of 71 and $81 \%$ for toluene and naphthalene, respectively. With the $\mathrm{RC}$, the toluene and naphthalene conversions remained steady at $850{ }^{\circ} \mathrm{C}$, indicating that catalysts endure the deactivation by coke. Worth noting is that even if the benzene conversion decreased, since benzene is not as problematic as the other model tars, less intensive treatments may be used for its eradication.
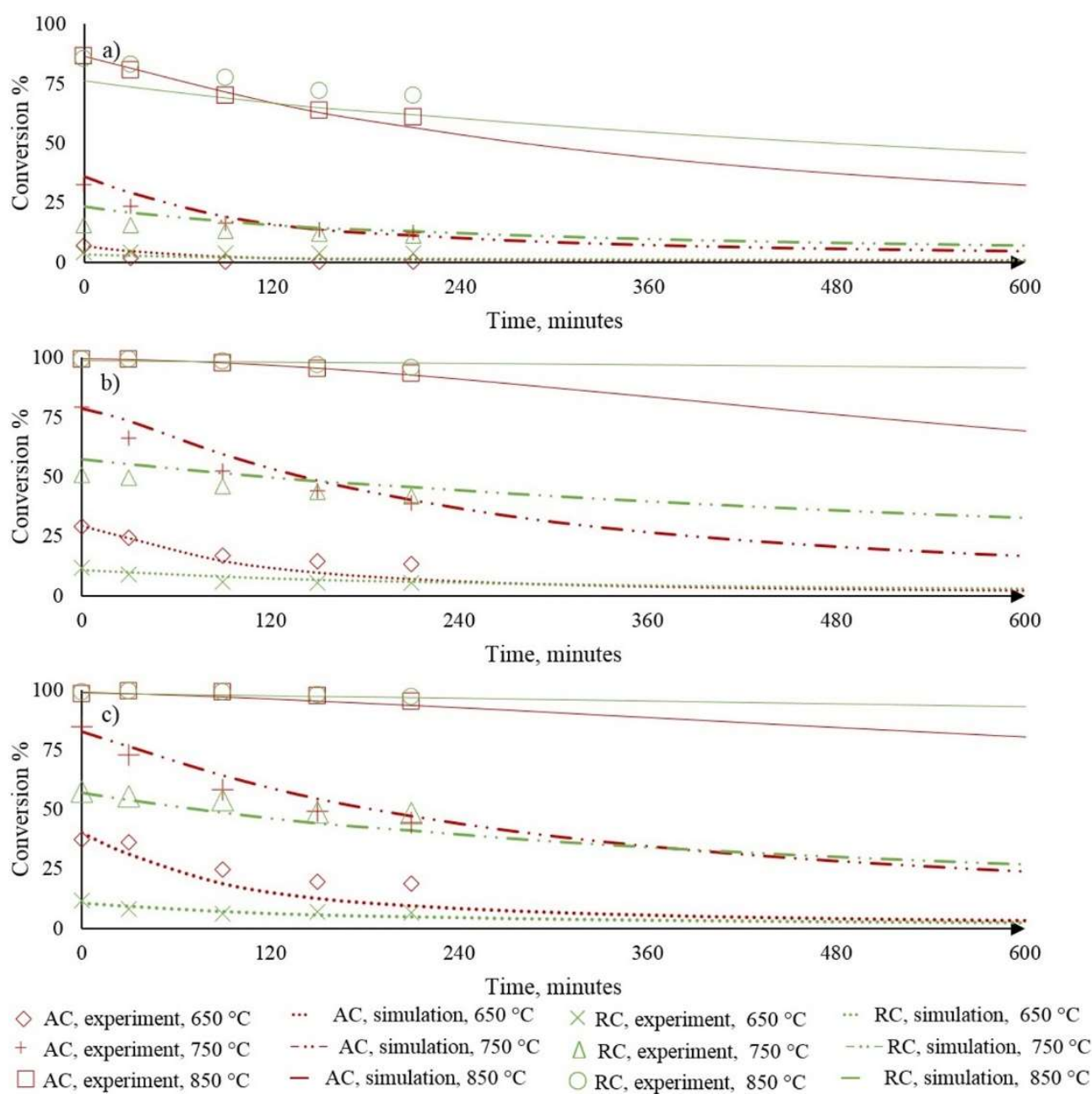

Figure 6. Results from the catalyst deactivation simulations. Lines correspond to simulations whilst symbols correspond to experiments. a) Benzene; b) toluene; c) naphthalene.

\subsection{Characterization of the catalysts}

\subsubsection{Surface functional groups}

Chars are known to have compounds such as polyaromatic hydrocarbons and functional groups such as carboxylic, lactonic, carbonyl, phenolic and phenoxide on their surface [43]. The presence of O- radicals that adsorb polar molecules, and $\mathrm{H}$ - radicals that catalyze the cleavage of $\mathrm{C}-\mathrm{C}$ and $\mathrm{C}-\mathrm{H}$ bonds in the char surface was determined by FTIR $[44,45]$. Regular, activated char and spent activated char were subject to the analysis; 
results are found in Figure 7. Bands were found at 2690-2840, 2300-2360, 2150-2212 and 1900-2000 cm-1 and correspond to $\mathrm{C}-\mathrm{H}, \mathrm{C}=\mathrm{O}, \mathrm{C}-\mathrm{O}$ and $\mathrm{C}=\mathrm{C}$ stretching vibrations, respectively [33,46]. Additionally, low intensity peaks were found in the intervals between $1580-1680 \mathrm{~cm}^{-1}$, corresponding to $\mathrm{C}=\mathrm{C}$ bond stretching [34]. In the case of the regular char, an additional peak was detected at $870 \mathrm{~cm}^{-1}$ associated with $=\mathrm{C}-\mathrm{H}$ bonds [34]. The three chars qualitatively presented the same FTIR profile with differences in the peak intensities; the fresh RC had the highest transmittance while the spent AC had the least. Although it appears that the chars have very different peak intensities, the relative intensities between the functional groups in the chars are largely the same, and the observable differences are owed to different baseline transmittances due to changes in the physical structure of the solids and the qualitative nature of the analytical technique employed [34]. However, it is notable that there are differences in the relative peaks corresponding to $\mathrm{C}=\mathrm{O}$ bond vibrations (2300-2360 $\mathrm{cm}^{-1}$ ) between the fresh chars and the spent char. This difference occurs due to oxidation of the carbonaceous matrix in the spent chars [13]. Therefore, from the FTIR profiles and the observed conversions it can be deducted that the differences in the initial char catalytic activity comes mainly from the surface area and not from functional groups.

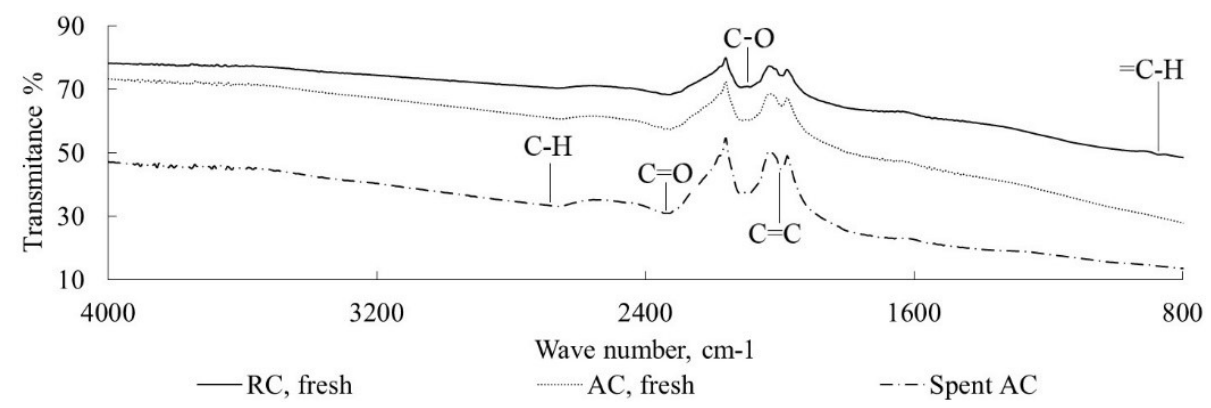

Figure 7. FTIR spectra of different char catalysts.

\subsubsection{Porous structure}

Table 2 presents the BET surface areas, average pore diameter, micropore area and micropore volume of the chars before and after 3 hours of use. The surface characteristics of the chars from references $[11,14,20]$ are also included for comparison purposes (see section 4). Expectedly, the activated char exhibited a higher initial micropore area, specific surface area and average micropore diameter than the regular char. Both chars exhibited Type I adsorption isotherms and hysteresis loops characteristic of micro and mesoporous carbon structures [47]. Moreover, the hysteresis loop found in the $\mathrm{AC}$, between 0.45 and 0.99 relative pressure, is characteristic of materials with a combination of micropores and mesopores with micropore networks in the char matrix $[47,48]$. The adsorption isotherms for the chars can be found in the supplementary material.

Table 2. Surface characteristics of the char particles from this work and char-based catalysts used in references. N/A: Data not reported.

\begin{tabular}{|c|c|c|c|c|c|c|}
\hline Char type & Description & $\begin{array}{l}\text { BET surface } \\
\text { area }\left(\mathrm{m}^{2} / \mathrm{g}\right)\end{array}$ & $\begin{array}{l}\text { Average pore } \\
\text { diameter }(\AA)\end{array}$ & $\begin{array}{l}\text { Micropore } \\
\text { area }\left(\mathrm{m}^{2} / \mathrm{g}\right)\end{array}$ & $\begin{array}{c}\text { Micropore } \\
\text { volume }\left(\mathrm{cm}^{3} / \mathrm{g}\right)\end{array}$ & Ref. \\
\hline \multirow[t]{4}{*}{ Hardwood char } & Fresh char & 232 & 14.1 & 110 & 0.10 & \multirow{4}{*}{$\begin{array}{l}\text { This } \\
\text { work }\end{array}$} \\
\hline & Reforming@650 ${ }^{\circ} \mathrm{C}$ for $180 \mathrm{~min}$. & 109 & 19.2 & 45 & 0.04 & \\
\hline & Reforming@750 ${ }^{\circ} \mathrm{C}$ for $180 \mathrm{~min}$. & 299 & 43.7 & 150 & 0.05 & \\
\hline & Reforming@850 ${ }^{\circ} \mathrm{C}$ for $180 \mathrm{~min}$. & 555 & 50.9 & 320 & 0.07 & \\
\hline \multirow{4}{*}{$\begin{array}{c}\text { Activated } \\
\text { hardwood char }\end{array}$} & Fresh char & 332 & 18.7 & 188 & 0.14 & \multirow{4}{*}{$\begin{array}{l}\text { This } \\
\text { work }\end{array}$} \\
\hline & Reforming@650 ${ }^{\circ} \mathrm{C}$ for $180 \mathrm{~min}$. & 244 & 32.1 & 65 & 0.07 & \\
\hline & Reforming@750 ${ }^{\circ} \mathrm{C}$ for $180 \mathrm{~min}$. & 354 & 44.3 & 245 & 0.03 & \\
\hline & Reforming@850 ${ }^{\circ} \mathrm{C}$ for $180 \mathrm{~min}$. & 612 & 52.8 & 361 & 0.08 & \\
\hline \multirow[t]{3}{*}{ Coconut char } & Fresh & 597 & N/A & 482 & 0.27 & \multirow{3}{*}[14]{} \\
\hline & Reforming@ $750^{\circ} \mathrm{C}$ for $75 \mathrm{~min}$. & 435 & N/A & 348 & 0.20 & \\
\hline & Reforming@850 ${ }^{\circ} \mathrm{C}$ for $75 \mathrm{~min}$. & 484 & N/A & 397 & 0.22 & \\
\hline
\end{tabular}




\begin{tabular}{|c|c|c|c|c|c|c|}
\hline & Reforming@ $950^{\circ} \mathrm{C}$ for $75 \mathrm{~min}$. & 677 & $\mathrm{~N} / \mathrm{A}$ & 540 & 0.30 & \\
\hline \multirow[t]{4}{*}{ Coal char } & Fresh & 635 & N/A & 375 & 0.21 & \multirow{4}{*}[14]{} \\
\hline & Reforming@ $750^{\circ} \mathrm{C}$ for $75 \mathrm{~min}$. & 264 & $\mathrm{~N} / \mathrm{A}$ & 111 & 0.06 & \\
\hline & Reforming@850 $\mathrm{C}$ for $75 \mathrm{~min}$. & 269 & N/A & 123 & 0.07 & \\
\hline & Reforming@ $950{ }^{\circ} \mathrm{C}$ for $75 \mathrm{~min}$ & 916 & $\mathrm{~N} / \mathrm{A}$ & 512 & 0.29 & \\
\hline \multirow{4}{*}{$\begin{array}{c}\text { Dry sewage sludge } \\
\text { char }\end{array}$} & Fresh & 55 & N/A & 17 & 0.01 & \multirow{4}{*}[14]{} \\
\hline & Reforming@ $750^{\circ} \mathrm{C}$ for $75 \mathrm{~min}$. & 65 & $\mathrm{~N} / \mathrm{A}$ & 14 & 0.01 & \\
\hline & Reforming@850 ${ }^{\circ} \mathrm{C}$ for $75 \mathrm{~min}$. & 41 & $\mathrm{~N} / \mathrm{A}$ & 4 & 0.00 & \\
\hline & Reforming@950 ${ }^{\circ} \mathrm{C}$ for $75 \mathrm{~min}$. & 55 & N/A & 8 & 0.00 & \\
\hline Commercial AC & Fresh & 1100 & N/A & 727 & 0.92 & {$[20]$} \\
\hline Wood char & Fresh & 633 & N/A & 474 & 0.19 & {$[20]$} \\
\hline $\begin{array}{l}\text { Activated wood } \\
\text { char }\end{array}$ & Fresh & 832 & N/A & 870 & 0.25 & [20] \\
\hline Wood char & Fresh & 51 & N/A & $\mathrm{N} / \mathrm{A}$ & $\mathrm{N} / \mathrm{A}$ & [11] \\
\hline $\begin{array}{l}\text { Activated wood } \\
\text { char }\end{array}$ & Fresh & 625 & $\mathrm{~N} / \mathrm{A}$ & $\mathrm{N} / \mathrm{A}$ & 0.27 & [11] \\
\hline $\begin{array}{l}\text { Food waste / sludge } \\
\text { char }\end{array}$ & Fresh & 10 & $\mathrm{~N} / \mathrm{A}$ & $\mathrm{N} / \mathrm{A}$ & $\mathrm{N} / \mathrm{A}$ & [11] \\
\hline $\begin{array}{l}\text { Activated food } \\
\text { waste /sludge char }\end{array}$ & Fresh & 221 & $\mathrm{~N} / \mathrm{A}$ & $\mathrm{N} / \mathrm{A}$ & 0.1 & [11] \\
\hline
\end{tabular}

\subsubsection{Scanning Electron Microscope and Energy Dispersive Spectroscopy}

Snapshots of the particles (obtained with SEM) and EDS map scanning results can be found in Figure 8. Figure 8a portrays the RC particles while Figure $8 \mathrm{~b}$ shows the AC particles. Evidently, the AC particles exhibit a larger amount of slit-shaped micropores, in agreement with the BET characterization results.
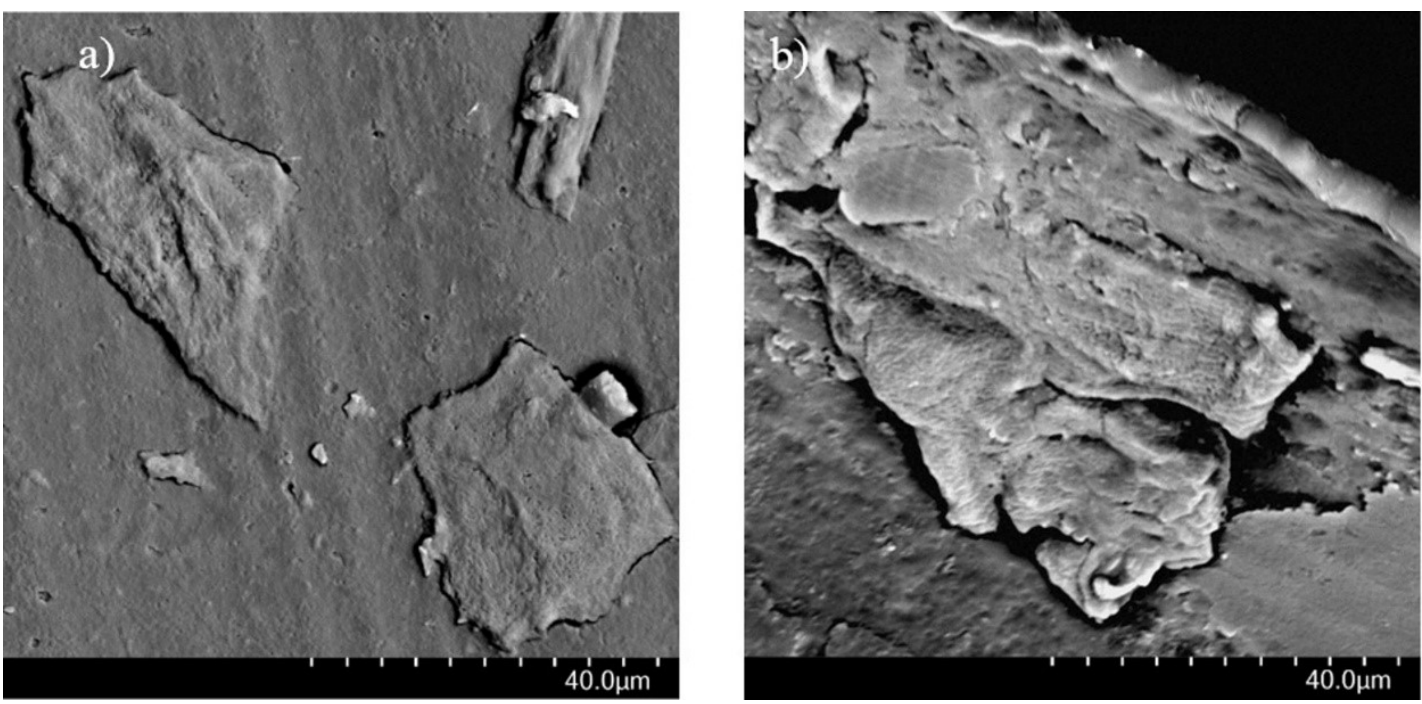

Figure 8. SEM snapshots and EDS map scans of (a) Regular char and (b) Activated char.

The EDS scans provide qualitative and semi-quantitative information of the distinct species present in a material.

Besides the expected elements ( $\mathrm{C}$ and $\mathrm{O}$ ), $\mathrm{Si}, \mathrm{Na}, \mathrm{Cl}, \mathrm{K}$ and $\mathrm{Ca}$ were found in both types of char, as depicted in the map scans from Figure 9. The Au spectra correspond to the gold coating used to enhance the electrical conductivity and are therefore ignored in the analysis. 

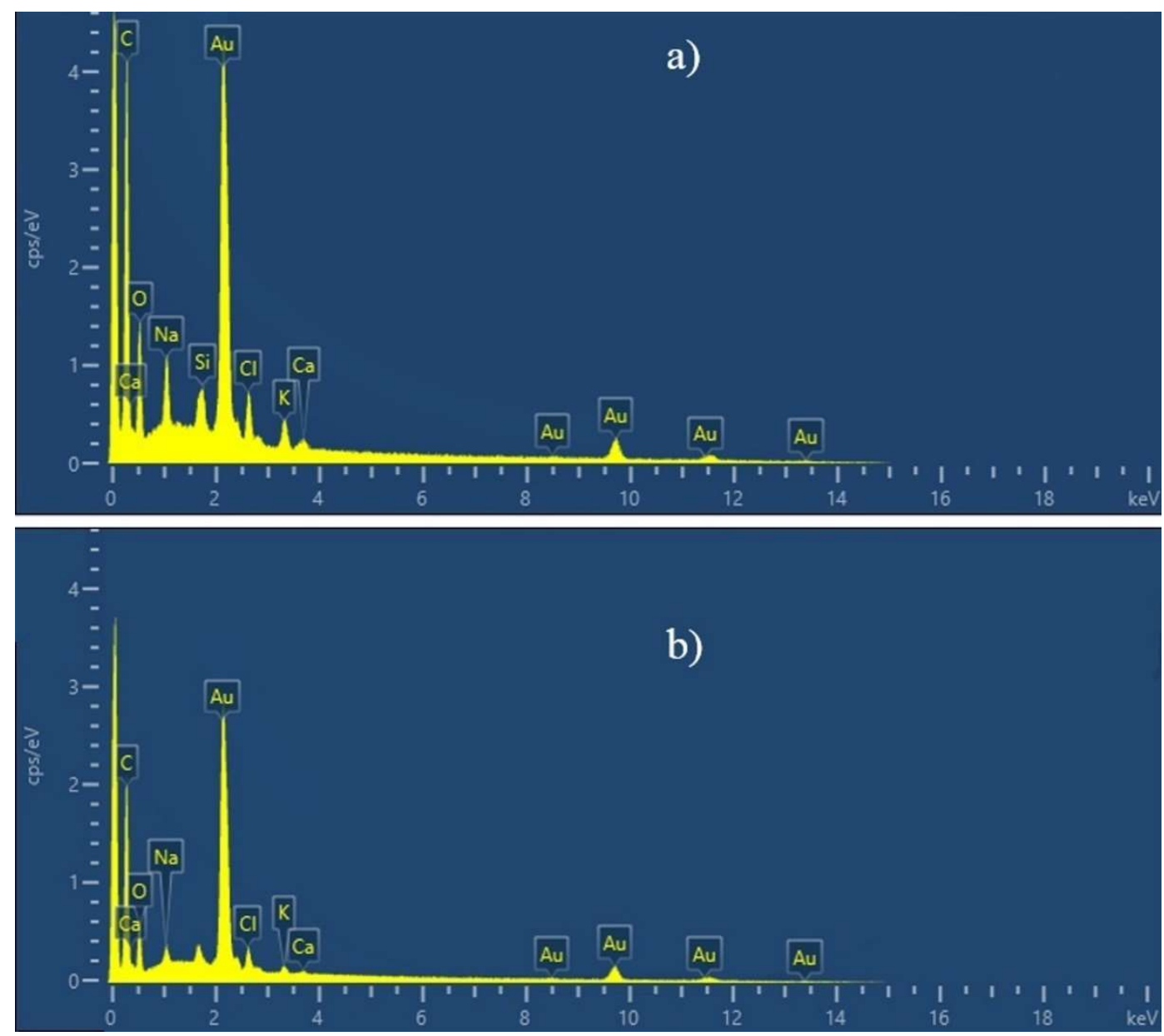

Figure 9. EDS area scans of (a) Regular char and (b) Activated char.

An area scan of the regular char and activated char particles is found in Figures 9a and 9b, respectively. There are small differences between the peak intensities of the $\mathrm{Na}, \mathrm{Si}, \mathrm{Cl}, \mathrm{K}$ and $\mathrm{Ca}$ in the $\mathrm{RC}$ and the $\mathrm{AC}$, where the peak intensities appear slightly lower in the AC [12].

\section{Discussion}

FTIR profiles were qualitatively the same for all the studied chars, this indicates the differences in their catalytic activity and produced gases are related to the char porous structure but not the surface functional groups, and both chars exhibit qualitatively same inorganic species with existence of slight differences according to the EDS spectra. The differences support the attribution of the catalytic effect to surface area, as $\mathrm{Ca}$ and $\mathrm{K}$ have catalytic capabilities in their oxidized form [49], and have less prevalence in the AC, which has more reforming capabilities than the RC.

A range of reports that have been made on the catalytic decomposition of tar model compounds using chars are hereby presented for comparison purposes. In [20] complete benzene conversion was achieved with activated char at $850{ }^{\circ} \mathrm{C}$ under pyrolysis conditions; the used chars had micropore areas of more than $800 \mathrm{~m}^{2} / \mathrm{g}$. In another work using benzene as a model compound [11], around 100\% of the benzene was converted using biochar with a specific surface area of $625 \mathrm{~m}^{2} / \mathrm{g}$ and $850{ }^{\circ} \mathrm{C}$ as reactor temperature, although the employed catalyst showed an abrupt deactivation during the first 10 minutes. Fuentes-Cano et al. [14] used different chars (produced from coconut, dried sewage sludge and coal) to reform a mixture of $12 \mathrm{~g} / \mathrm{Nm}^{3}$ of toluene and $8 \mathrm{~g} / \mathrm{Nm}^{3}$ of naphthalene 
at 750,850 and $950{ }^{\circ} \mathrm{C}$ with a gas residence time in the char bed of 0.3 seconds. In their results, the catalysts presented significant losses of activity after about 30 minutes, even at a temperature of $950{ }^{\circ} \mathrm{C}$. By comparison, the char used in this work provided conversions higher than $90 \%$ for more than three hours. All in all, when compared with this work, the experiments from the mentioned references exhibited initially higher conversions, but in every case the catalysts deactivated more severely. The differences in the catalytic activity are associated to the distribution of the char surface area and porosity.

A comparison between the conversions of toluene and naphthalene across time from this work and results from [14] is found in Figure 10. As depicted in the figure, the losses of activity using a microporous coconut char from [14] to reform naphthalene were noticeably larger than the losses experienced by the catalysts from this work. This phenomenon can be explained by paying attention to the surface characteristics of the compared catalysts. As seen in Table 1, the coconut chars had an initially larger BET surface area and a significantly higher micropore area than all the chars from this work. The micropores responsible for high initial tar conversions were quickly blocked by coke; these pores were not reopened with steam throughout the reforming experiments. It is possible that hydrogen produced from cracking restricts the access of the gasifying agent to sites located deep in the char matrix [50].
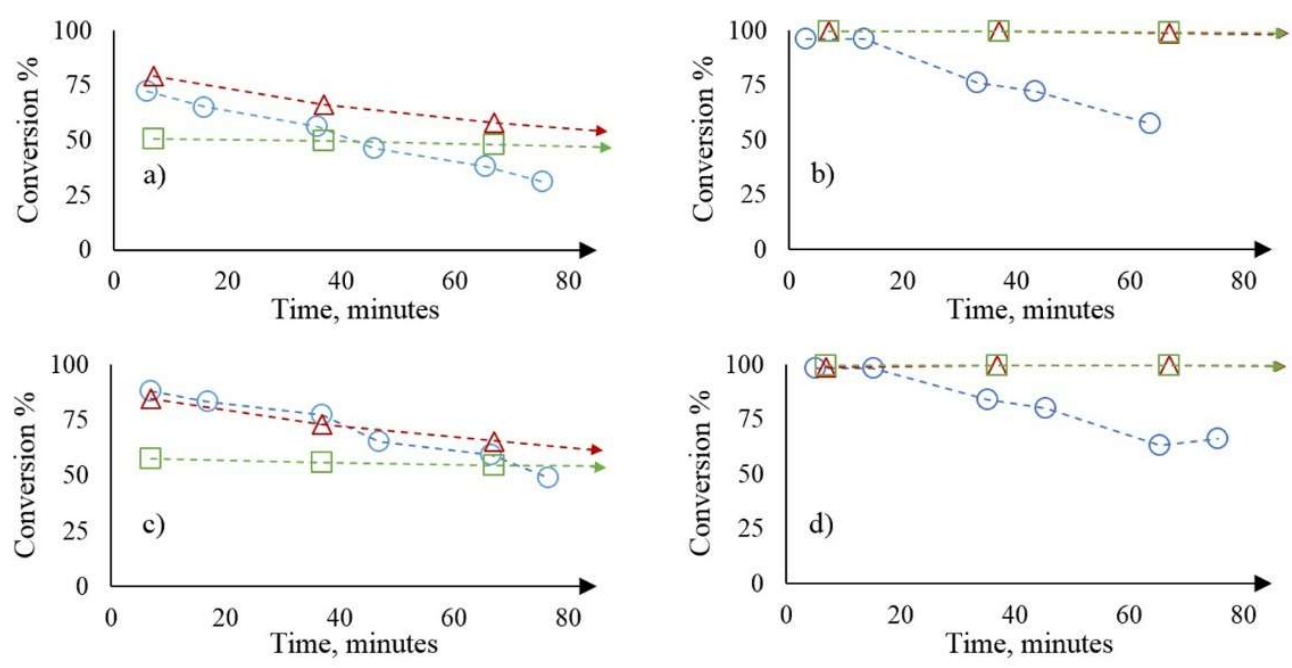

Fuentes-Cano et al $\Delta$ Activated char $\square$ Regular char

Figure 10. Comparison of the activity of the catalysts used in this work and coconut char catalyst from reference [14]: a) toluene reforming at $750^{\circ} \mathrm{C}$; b) toluene reforming at $850^{\circ} \mathrm{C}$; c) naphthalene reforming at $750{ }^{\circ} \mathrm{C}$; d) naphthalene reforming at $850{ }^{\circ} \mathrm{C}$. Data extracted from Fuentes-Cano D. et al, "Decomposition kinetics of model tar compounds over chars with different internal structure to model hot tar removal in biomass gasification". Chem Eng J 2013;228:1223-33. Copyright 2013, Elsevier.

Although the surface areas of both catalysts from this work appeared to increase after being used for reforming, the micropore areas and volumes decreased for every case. On the other hand, even if the initial micropore volumes decreased, at $850^{\circ} \mathrm{C}$ the specific surface areas, average pore diameters and micropore areas increased, creating new active sites. Moreover, during reforming at $850{ }^{\circ} \mathrm{C}$ the porous features were almost the same for both char catalysts, explaining their similar resilience and conversion rate at that temperature. The steeper decrease in conversion using $\mathrm{AC}$ when compared to the RC occurred because of its originally more microporous structure. It has been reported that the catalytic resistance of the char comes from high surface area serving as a "reservoir" to adsorb coke [11]. However, from the observed catalytic behavior, products and conversions, it was determined that during reforming, the catalyst deactivation resistance does not depend on surface area. The resistance of the catalyst stems from the abundance of mesopores in the char matrix. While the 
micropores contribute to the initially high catalytic reforming activity, mesoporous chars provide surface active sites which are less prone to diffusion limitations and more resistant to coke. From the surface area characterization, it was concluded that in the presence of steam, the coke deposited in macro and mesopores can be gasified at sufficiently high temperatures $\left(850{ }^{\circ} \mathrm{C}\right.$ in this work), while the coke deposited in micropores could not be gasified under any of the studied conditions due to mass transfer limitations and strong molecular interactions between the polyaromatic hydrocarbons composing the coke [8,51].

While it appears that there are loses in benzene conversion over time, what actually occurs is that after the micropores are completely blocked by coke, the toluene starts decomposing into benzene, this is indeed in agreement with [18]. This explains the changes in the obtained products across time (e.g. the amount of $\mathrm{H}_{2}$ produced decreases, as shown in Figure 5), and indicates that different reaction pathways are followed depending on the status of the active sites on the char surface. Even if reforming can occur with reactivated char, for constant heterogeneous reforming via coke deposition then gasification, conserving the active sites in the micropores is necessary.

\section{Summary and conclusions}

Experiments using biochar and activated biochar as a catalyst for reforming a mixture of tars at different temperatures were conducted in this work. Although the chars provided different levels of conversion, during tar reforming both led to the production of gases $\left(\mathrm{CO}, \mathrm{CO}_{2}, \mathrm{H}_{2}, \mathrm{CH}_{4}\right)$ in similar proportions, initially and across time. Moreover, at $850^{\circ} \mathrm{C}$, the highest studied temperature, none of the chars exhibited significant deactivation. It was concluded that:

- The coke deposited in macro and meso pores can be gasified in the presence of steam and at sufficiently high temperatures $\left(850^{\circ} \mathrm{C}\right.$ in the studied conditions), preventing decreases in specific surface area and reforming activity. On the other hand, although microporous chars provide a higher initial tar conversion than their mesoporous counterparts, microporous chars are quickly deactivated due to coking. Under the studied conditions it was not possible to preserve micropores in the char surface.

- The reforming activity of the char depends mainly on its surface area, while the reforming mechanism followed by the tars with char depends on the active sites inside pores. When the active sites in the char surface are blocked, the tar stops depositing in the form of coke and reforms homogeneously. The followed reforming mechanism affects the tar reforming capabilities. For example, after the active sites in the micropores were coked, the decomposition of toluene resulted in the formation of the more stable benzene, and decreases in total tar conversion.

- The results from the simulations using the kinetic parameters obtained from the laboratory experiments showed a good agreement when compared with the experimental results. Additional simulations of reforming during 10 hours were conducted, which showed that at $850{ }^{\circ} \mathrm{C}$, more than $90 \%$ of the toluene and naphthalene, and around $50 \%$ of the benzene in the tar mixture were removed using regular char as a catalyst.

The findings from this work present the relevance of biochar, specifically meso and macroporous, as stable catalysts for tar reforming. While the experiments conducted were relatively short in duration, the findings 
provide an insight for the design of future experiments during longer operation times. This can consolidate the resilience of char-based catalysts in an industrial scale.

\section{Acknowledgements}

The author would like to thank the Consejo Nacional de Ciencia y Tecnología (CONACYT) and BRISK2 for the financial support provided for this research. Special thanks to Mari-Leena Koskinen-Soivi and Petri Hietula from VTT for their valuable assistance in conducting the experimental part of this work, Ryan McFadden for his help conducting the SEM/EDS analysis and Alexander Shaw for his English language assistance.

\section{Declaration of interest}

None.

\section{References}

[1] Brown RC. Thermochemical Processing of Biomass: Conversion into Fuels, Chemicals and Power. 2011. doi:10.1002/9781119990840.

[2] Zhang X. Essential scientific mapping of the value chain of thermochemically converted second-generation bio-fuels. Green Chem 2016;18:5086-117. doi:10.1039/C6GC02335E.

[3] Abdoulmoumine N, Adhikari S, Kulkarni A, Chattanathan S. A review on biomass gasification syngas cleanup. Appl Energy 2015;155:294-307. doi:10.1016/j.apenergy.2015.05.095.

[4] Jess A. Mechanisms and Kinetics of Thermal Reactions of Aromatics From Pyrolysis of Solid Fuels. Fuel 1996;75:1441-8.

[5] Shen Y, Zhao P, Shao Q, Ma D, Takahashi F, Yoshikawa K. In-situ catalytic conversion of tar using rice husk char-supported nickel-iron catalysts for biomass pyrolysis/gasification. Appl Catal B Environ 2014;152-153:140-51. doi:10.1016/j.apcatb.2014.01.032.

[6] Adnan MA, Muraza O, Razzak SA, Hossain MM, de Lasa HI. Iron Oxide over Silica-Doped Alumina Catalyst for Catalytic Steam Reforming of Toluene as a Surrogate Tar Biomass Species. Energy \& Fuels 2017;31:7471-81. doi:10.1021/acs.energyfuels.7b01301.

[7] Xu C, Donald J, Byambajav E, Ohtsuka Y. Recent advances in catalysts for hot-gas removal of tar and NH3 from biomass gasification. Fuel 2010;89:1784-95. doi:10.1016/j.fuel.2010.02.014.

[8] Buentello-Montoya DA, Zhang X, Li J. The use of gasification solid products as catalysts for tar reforming. Renew Sustain Energy Rev 2019;107:399-412. doi:10.1016/j.rser.2019.03.021.

[9] Abu El-Rub Z, Bramer EA, Brem G. Experimental comparison of biomass chars with other catalysts for tar reduction. Fuel 2008;87:2243-52. doi:10.1016/j.fuel.2008.01.004.

[10] Abu El-Rub Z. Tar reduction in biomass gasification using biomass char as a catalyst. Proceeding Conf Technol Exhib Biomass Energy, Ind Clim Prot 2004:1046-9.

[11] Hervy M, Weiss-hortala E, Pham D, Dib H, Villot A, Gérente C, et al. Reactivity and deactivation mechanisms of pyrolysis chars from bio-waste during catalytic cracking of tar. Appl Energy 2019;237:487-99. doi:10.1016/j.apenergy.2019.01.021.

[12] Mani S, Kastner JR, Juneja A. Catalytic decomposition of toluene using a biomass derived catalyst. Fuel Process Technol 2013;114:118-25. doi:10.1016/j.fuproc.2013.03.015.

[13] Hervy M, Villot A, Gérente C, Pham D, Weiss-hortala E, Nzihou A, et al. Catalytic cracking of ethylbenzene as tar surrogate using pyrolysis chars from wastes. Biomass and Bioenergy 2018;117:86-95. doi:10.1016/j.biombioe.2018.07.020.

[14] Fuentes-Cano D, Gómez-Barea A, Nilsson S, Ollero P. Decomposition kinetics of model tar compounds over chars with different internal structure to model hot tar removal in biomass gasification. Chem Eng J 2013;228:1223-33. doi:10.1016/j.cej.2013.03.130.

[15] Hosokai S, Kumabe K, Ohshita M, Norinaga K, Li CZ, Hayashi J ichiro. Mechanism of decomposition of aromatics over charcoal and necessary condition for maintaining its activity. Fuel 2008;87:2914-22. doi:10.1016/j.fuel.2008.04.019.

[16] Song Y, Wang Y, Hu X, Xiang J, Hu S, Mourant D, et al. Effects of volatile-char interactions on in-situ destruction of nascent tar during the pyrolysis and gasification of biomass. Part II. Roles of steam. Fuel 2015;143:555-62. doi:10.1016/j.fuel.2014.11.096.

[17] Min Z, Yimsiri P, Asadullah M, Zhang S, Li CZ. Catalytic reforming of tar during gasification. Part II. Char as a catalyst or as a catalyst support for tar reforming. Fuel 2011;90:2545-52. doi:10.1016/j.fuel.2011.03.027.

[18] Korus A, Samson A, Szlęk A, Katelbach-Woźniak A, Sładek S. Pyrolytic toluene conversion to benzene and coke over activated carbon in a fixed-bed reactor. Fuel 2017;207:283-92. doi:10.1016/j.fuel.2017.06.088.

[19] Acharya CK, Jiang F, Liao CH, Fitzgerald P, Vecchio KS, Cattolica RJ. Tar and CO2 removal from simulated producer gas with activated carbon and charcoal. Fuel Process Technol 2013;106:201-8. doi:10.1016/j.fuproc.2012.07.026.

[20] Burhenne L, Aicher T. Benzene removal over a fixed bed of wood char: The effect of pyrolysis temperature and activation with CO2 on the char reactivity. Fuel Process Technol 2014;127:140-8. doi:10.1016/j.fuproc.2014.05.034.

[21] Feng D, Zhao Y, Zhang Y, Zhang Z, Xu H, Zhang L, et al. Synergies and progressive effects of H2O/CO2 and nascent tar on biochar structure and reactivity during gasification. Fuel Process Technol 2017;168:1-10. doi:10.1016/j.fuproc.2017.08.030.

[22] Font Palma C. Modelling of tar formation and evolution for biomass gasification: A review. Appl Energy 2013;111:129-41. doi:10.1016/j.apenergy.2013.04.082.

[23] Coll R, Salvadó J, Farriol X, Montané D. Steam reforming model compounds of biomass gasification tars: Conversion at different operating conditions and tendency towards coke formation. Fuel Process Technol 2001;74:19-31. doi:10.1016/S03783820(01)00214-4.

[24] Rodriguez-Reinoso F, Molina-Sabio M, Gonzalez MT. The use of steam and CO2 as activating agents in the preparations of activated carbon. Carbon N Y 1995;33:15-23.

[25] Feng D, Zhao Y, Zhang Y, Sun S. Effects of H2O and CO2on the homogeneous conversion and heterogeneous reforming of biomass tar over biochar. Int J Hydrogen Energy 2017;42:13070-84. doi:10.1016/j.ijhydene.2017.04.018. 
[26] Murillo R, Navarro M V., López JM, García T, Callén MS, Aylón E, et al. Activation of pyrolytic lignite char with CO2. Kinetic study. Energy and Fuels 2006;20:11-6. doi:10.1021/ef0501187.

[27] TENGYAN ZHANG ${ }^{a}$, WALTER P. WALAWENDER ${ }^{\text {a }}$ *, L. T. FAN ${ }^{\mathrm{a}}$, MAOHONG FANb, DAREN DAUGAARDb ARCBrown ${ }^{a}$ Department. Preparation of Activated Carbon From Forest and Agricultural 2005.

[28] David E, Kopac J. Activated carbons derived from residual biomass pyrolysis and their CO2 adsorption capacity. J Anal Appl Pyrolysis 2014;110:322-32. doi:10.1016/j.jaap.2014.09.021.

[29] Herawan SG, Hadi MS, Ayob MR, Putra A. Characterization of activated carbons from oil-palm shell by CO2 activation with no holding carbonization temperature. Sci World J 2013;2013. doi:10.1155/2013/624865.

[30] Maneerung T, Liew J, Dai Y, Kawi S, Chong C, Wang CH. Activated carbon derived from carbon residue from biomass gasification and its application for dye adsorption: Kinetics, isotherms and thermodynamic studies. Bioresour Technol 2016;200:350-9. doi:10.1016/j.biortech.2015.10.047.

[31] Yang K, Peng J, Srinivasakannan C, Zhang L, Xia H, Duan X. Preparation of high surface area activated carbon from coconut shells using microwave heating. Bioresour Technol 2010;101:6163-9. doi:10.1016/j.biortech.2010.03.001.

[32] Rodr??guez-Reinoso F, Molina-Sabio M. Activated carbons from lignocellulosic materials by chemical and/or physical activation: an overview. Carbon N Y 1992;30:1111-8. doi:10.1016/0008-6223(92)90143-K.

[33] Gaspard S, Altenor S, Dawson EA, Barnes PA, Ouensanga A. Activated carbon from vetiver roots: Gas and liquid adsorption studies. J Hazard Mater 2007;144:73-81. doi:10.1016/j.jhazmat.2006.09.089.

[34] Coates J. Interpretation of Infrared Spectra, A Practical Approach. Encycl Anal Chem 2006:1-23. doi:10.1002/9780470027318.a5606.

[35] Yu J, Lucas J, Strezov V, Wall T. Swelling and char structures from density fractions of pulverized coal. Energy and Fuels 2003;17:1160-74. doi:10.1021/ef030022h.

[36] Dou B, Gao J, Sha X, Baek SW. Catalytic cracking of tar component from high-temperature fuel gas. Appl Therm Eng 2003;23:2229-39. doi:10.1016/S1359-4311(03)00185-6.

[37] Scott Fogler H. Elements of chemical reaction engineering. Chem Eng Sci 2002. doi:10.1016/0009-2509(87)80130-6.

[38] Voorhies A. Carbon formation in catalytic cracking. Ind Eng Chem 1945;37:318-22. doi:10.1021/ie50424a010.

[39] Goodwin DG, Moffat HK, Speth RL. Cantera: An object-oriented software toolkit for chemical kinetics, thermodynamics, and transport processes. Http://WwwCanteraOrg 2017. doi:10.5281/zenodo.170284.

[40] Kaisalo N, Simell P, Lehtonen J. Benzene steam reforming kinetics in biomass gasification gas cleaning. Fuel 2016;182:696-703. doi:10.1016/j.fuel.2016.06.042.

[41] Klaewkla R, Arend M, F. W. A Review of Mass Transfer Controlling the Reaction Rate in Heterogeneous Catalytic Systems. Mass Transf - Adv Asp 2011. doi:10.5772/22962.

[42] Levenspiel O. Chemical Reaction Engineering. Ind Eng Chem Res 1999;38:4140-3. doi:10.1021/ie990488g.

[43] Lapuerta M, Monedero E, Hern JJ. Characterisation of residual char from biomass gasi fi cation : effect of the gasi fi er operating conditions 2016;138:83-93. doi:10.1016/j.jclepro.2016.05.120.

[44] Vassilev S V., Baxter D, Andersen LK, Vassileva CG. An overview of the composition and application of biomass ash.: Part 2. Potential utilisation, technological and ecological advantages and challenges. Fuel 2013;105:19-39. doi:10.1016/j.fuel.2012.10.001.

[45] Benedetti V, Patuzzi F, Baratieri M. Characterization of char from biomass gasification and its similarities with activated carbon in adsorption applications. Appl Energy 2017:1-8. doi:10.1016/j.apenergy.2017.08.076.

[46] Shen DK, Gu S, Bridgwater A V. Study on the pyrolytic behaviour of xylan-based hemicellulose using TG-FTIR and Py-GCFTIR. J Anal Appl Pyrolysis 2010;87:199-206. doi:10.1016/j.jaap.2009.12.001.

[47] Thommes M, Kaneko K, Neimark A V., Olivier JP, Rodriguez-Reinoso F, Rouquerol J, et al. Physisorption of gases, with special reference to the evaluation of surface area and pore size distribution (IUPAC Technical Report). Pure Appl Chem 2015;87:105169. doi:10.1515/pac-2014-1117.

[48] Groen JC, Peffer LAA, Pérez-Ramírez J. Pore size determination in modified micro- and mesoporous materials. Pitfalls and limitations in gas adsorption data analysis. Microporous Mesoporous Mater 2003;60:1-17. doi:10.1016/S1387-1811(03)00339-1.

[49] Feng D, Zhao Y, Zhang Y, Zhang Z, Sun S. Roles and fates of K and Ca species on biochar structure during in-situ tar H2O reforming over nascent biochar. Int J Hydrogen Energy 2017:42:21686-96. doi:10.1016/j.ijhydene.2017.07.096.

[50] Dufour A, Celzard A, Fierro V, Martin E, Broust F, Zoulalian A. Catalytic decomposition of methane over a wood char concurrently activated by a pyrolysis gas. Appl Catal A Gen 2008;346:164-73. doi:10.1016/j.apcata.2008.05.023.

[51] Liu X, Zhou ZJ, Zhang BS, Chen L, Wang FC. Effect of microwave treatment on structural changes and gasification reactivity of petroleum coke. Ind Eng Chem Res 2011;50:9063-8. doi:10.1021/ie2007328. 